\title{
THE MERITS OF THE AUTOMOBILE ACCIDENT COMPENSATION PLAN
}

\author{
SHIPPEN LEWIS*
}

Four years ago a committee of lawyers and judges, which I shall hereafter call simply "the committee," completed a report on automobile accident compensation after a study which had been liberally financed by the Rockefeller Foundation and had lasted for over two years. ${ }^{1}$ The committee employed a large number of investigators to report on the financial and social effects of automobile accidents; it also employed statisticians, actuaries and an insurance adviser. It succeeded, I think, in presenting its findings of fact fairly and accurately. In writing the present article I feel justified in relying partly on the facts found by the committee, since I was the director of the study and was responsible for collecting its information.

This article presents the arguments in favor of an automobile accident compensation system, that is, a system of compensation with limited liability and without regard to fault, backed by compulsory insurance, analogous to workmen's compensation. I shall also comment on the arguments against such a system which seem to me to be either sound or plausible, and I shall discuss some of the details of such a system. The reader should also consult the committee's report itself; a criticism of the report by P. Tecumseh Sherman, Esq., consulting counsel to the Association of Casualty and Surety Executives, published in August, 1932; and, for a competent review of the whole subject, The Automobile Compensation Plan, by Patterson H. French, LL.B., Ph.D., published in I933 by the Columbia University Press.

\section{Compulsory Insurance}

It is, I believe, generally agreed among insurance men, public officials, lawyers and other students of the subject that some new system is needed to solve the problem of compensation for automobile accidents. Until very recently we have really had no system at all, for in each state we have relied upon the common law

- A.B., 1907, LL.B., I910, University of Pennsylvania. Member of the Pennsylvania Bar, practising in Philadelphia. Chairman of various committees of the Philadelphia and Pennsylvania Bar Associations to study automobile compensation and compulsory liability insurance and to draft legislation thereon. Director of the study by the Committee to Study Compensation for Automobile Accidents for the Columbia University Council for Research in the Social Sciences, 1928-1932. Editor of the Pennsylvania Bar Association Quarterly.

${ }^{2}$ Report by the Committee to Study Compensation for Automobile Accidents to the Columbia University Council for Research in the Social Sciences (Feb. I, I932). 
liability for negligence, with no requirement as to the financial responsibility of motorists, except certain statutes, ordinances and regulations covering taxis and buses. With the great increase in the number and speed of automobiles have come great increases in automobile accidents, in liability insurance and in accident litigation. By its very size the problem of automobile accident compensation has thrust itself on us, leading us to consider whether the financial responsibility of the motorist should be left entirely to chance and whether the doctrine of negligence is adequate as a measure of responsibility.

So far, no state has disturbed the doctrine of negligence. I shall therefore emulate the caution of the legislators and shall discuss first the question of financial responsibility and then the more radical question of the sanctity of the doctrine of negligence.

Assuming then that a motorist should be liable for injuries caused by his car only if he has been at fault, it is obvious that the injured person has no real remedy unless he can translate that liability into dollars and cents. The motorist may have run his car at 70 miles an hour through a crowd of school children; he may have neither brakes nor horn; he may be blind and deaf; in short, his neg'ligence may be so clear that no jury could hesitate for a moment to declare him liable; yet if he is financially irresponsible, a judgment against him is worthless. How many attorneys have been obliged to say to their clients, "You have serious injuries and a clear case, but the motorist has no property and no insurance and you will gain nothing by bringing suit."

Every experienced lawyer assumes that few uninsured motorists pay any compensation to their victims; and the committee's data tend strongly to confirm that assumption.

The wide difference between the chances of receiving compensation from insured and from uninsured motorists is shown by the following figures taken from the committee's report: ${ }^{2}$

\begin{tabular}{|c|c|c|}
\hline & $\begin{array}{c}\text { Insured } \\
\text { Percentage receiving } \\
\text { some compensation }\end{array}$ & $\begin{array}{l}\text { Not Insured } \\
\text { Percentage recciving } \\
\text { some compensation }\end{array}$ \\
\hline Temporary disabilities & . $\quad 86$ & 27 \\
\hline Permanent disabilities & 96 & $2 I$ \\
\hline Fatal cases $\ldots \ldots \ldots$ & 88 & I7 \\
\hline
\end{tabular}

When we consider the numbers of cases in which the net amounts received by the victims and their families cover the losses sustained, we are again struck by the difference between the insured and the uninsured motorists. In the following figures the loss in temporary disability cases includes wage and property loss and medical expense; in permanent disability cases it includes only wage loss and medical expense to the time of investigation; and in fatal cases it covers only medical and funeral expense.

\footnotetext{
${ }^{2}$ See CommitteE's Report, c. V.
} 


\begin{tabular}{|c|c|c|}
\hline & $\begin{array}{l}\text { Insured } \\
\text { Percentage in which } \\
\text { loss covered }\end{array}$ & $\begin{array}{l}\text { Not Insured } \\
\text { Percentage in which } \\
\text { loss covered }\end{array}$ \\
\hline Temporary disabilities & . 69 & II \\
\hline Permanent disabilities & 63 & 5 \\
\hline Fatal cases $\ldots \ldots \ldots$ & 77 & 7 \\
\hline
\end{tabular}

In I65 fatal cases insurance companies paid an average of $\$ x, 400$ each to meet medical and funeral losses averaging $\$ 57^{\circ}$; while in I29 other fatal cases uninsured motorists paid an average of $\$ 80$ each to meet losses averaging $\$ 600 .^{3}$

These figures are evidence that the chance of receiving compensation from an uninsured motorist is small, and that the chance of receiving adequate compensation is even smaller. Of course the figures are not positive proof of these conclusions, for they are drawn from only ten localities, and from only a tiny proportion of all the accident cases in the United States, and the data, though elicited by personal investigation, are necessarily inaccurate in some respects. The chance of receiving from uninsured motorists some compensation, however small, was greater in the cases studied in Connecticut than elsewhere; and since in Connecticut the investigators cross-checked their information more carefully than in other places, this suggests that the recorded proportions of non-payments outside of Connecticut are too small. But when it is considered that the cases studied in different localities were all run-of-the-mine cases taken from the public records, that the data from all localities as well as our common experience point in the same direction, and that it is reasonable to suppose that most of those with attachable property will protect themselves with liability insurance; when we consider all these things, we may safely conclude that a very large number of uninsured motorists fail to make adequate compensation for injuries caused by their negligence.

It has been gravely asserted that uninsured farmers as a class may be relied on to pay damages in automobile accident cases. ${ }^{4}$ The committee's case studies do not support this assertion, and it seems to contradict the political experience of many years. It is true that many farmers own their farms, but a judgment lien on the farm is not worth much if it is preceded by a mortgage. If a farmer owns land or anything else which is worth attaching, he is in the class of those most likely to insure.

I believe that there is certainly a large constant stream of automobile victims who are without remedy because the transgressors are without property and without insurance. For 1929 the National Bureau of Casualty and Surety Underwriters estimated that only $27.3 \%$ of all United States motor vehicles were insured for public

sId., Table 14, p. 271 .

'For example, Austin J. Lilly, Esq., general counsel for the Maryland Casualty Co., one of the ablest of the insurance company spokesmen, has said: "farmers and merchants in the remote rural districts who are already financially responsible do not insure." Compulsory Automobile Insurance, Compulsory Compensation for Motor Vehicle Injuries and Motor Vehicle Financial Responsibility Law, as discussed before the Committee on Motor Vehicle Legislation of the Ohio State Bar Association, January 3, 1930, with Later Annotations (Ass'n of Casualty and Surety Executives, 1932). 
liability, the state figures ranging from approximately $100 \%$ in Massachusetts to $6.4 \%$ in South Dakota. There have no doubt been increases since 1929 , but the number of uninsured cars is still very great in every state but Massachusetts.

I believe that this is an evil which calls for a cure. Still assuming for the moment that negligence is the proper basis of liability, I believe that the proper cure is compulsory automobile liability insurance, for I know of no other way of making sure, so far as possible, that every motorist is financially responsible. I believe that no one should be allowed to drive a death-dealing machine on the highways unless he can answer for the damage he does. I believe that in this regard automobiles should be treated differently from shot-guns, bicycles, horses and other things which often cause injuries, because the huge number of automobile accidents puts automobiles in a class by themselves, and because the present regulation of them facilitates further regulation.

Naturally, reasonable men differ on this question of compulsory insurance, just as they differ on the tariff, on methods of taxation, on banking laws, and on a thousand other matters involving the compulsory transfer of property from one body of men to another. As the Quakers say, different Friends are differently led. If you are very much concerned to protect the victims of accidents, you will probably favor compulsory insurance; if, on the other hand, your objection to control of the individual and to extension of the powers of government is stronger than your concern for the accident victims, you will probably oppose compulsory insurance. I know two conservative Philadelphia Republican lawyers who are partners; one opposes compulsory insurance, while the other favors not only compulsory insurance, but a plan of compensation without regard to fault.

Those unfamiliar with the subject will be surprised to learn that the stock insurance companies have so far opposed compulsory insurance with all their heart, with all their soul, with all their mind and with all their strength. I believe that the controlling reason for this opposition is fear of state insurance. If every motorist must insure, will there not soon be a demand for an insurance fund conducted by the state without cost? And if the state writes automobile liability insurance, why not life, fire and accident insurance as well? It is natural and proper that this possibility should disturb those who make their living in the insurance business, but to the rest of us the argument does not seem so strong. Even though we believe that the state should keep out of the insurance business, we are willing to face that problem when it-arises and are not so fearful of the future as to abstain from action simply because it may lead later to mistaken action.

The companies draw another argument against compulsory liability insurance from their experience in Massachusetts, the only state having that system. In Massachusetts an appointee of the governor fixes the premiums for the required insurance. Since the motorists muster many more votes than the insurance companies, political expediency has persistently produced rates unfair to the stock companies. Many companies have continued to write automobile liability insurance 
in Massachusetts, only because they want to carry a full line of insurance for every customer. Properly managed mutual companies have in general been able to pay dividends because they have no agents' commissions to pay.

If the state is to control premium rates, a system of compulsory insurance, whether for liability or for compensation, should take the fixing of rates out of politics so far as possible. The experience of many years in fixing railroad and utility rates will be useful in this connection. Though it may seem hard at first blush not only to require the insurance companies to write certain policies, but to fix their charges for doing so, yet this has for a long time been the price paid by other corporations for their privileges, and is in some cases the necessary alternative to direct state enterprise to accomplish something which the community must have.

Another argument against compulsory insurance is that it increases accidents. Apparently it is assumed that the motorist who has been obliged to insure against his will, takes chances which he otherwise would not take. It is also assumed that if the companies can be forced, as in Massachusetts, to accept risks which they want to refuse, the numbers of unfit drivers and cars and consequently the numbers of accidents will be increased because the public agency which passes on the risks is likely to be more lax than the companies are. A little reflection will show that these assumptions are unsound. As to the first, it is the fear of collision and of the criminal law which makes us drive carefully, rather than fear of personal liability in damages; if it were not so, all liability insurance would be an encouragement to negligence. As to the second, if the public authorities are lax in licensing unfit drivers and cars, they will certainly not be more so simply because there is compulsory liability insurance; indeed it should be easier to pass the scrutiny of the licensing authorities, with no opportunity given to anyone to object, than to pass the state insurance authorities when a carrier is giving hostile evidence.

In discussing the effect of compulsory insurance on accidents, opponents often cite figures from state accident records. These records are inaccurate and can be relied on to show only how many accidents and injuries are reported; they cannot be relied on to show how many accidents or injuries there have really been, or to show the effect of any law on the real number of accidents and injuries. If any reader doubts this statement I think he will be persuaded by reading pages ro3-108 and I25-127 of the committee's report. So far as I know there are no reliable statistics showing the effect on the accident rate of any law as to compensation.

Whether the motorist's liability is to pay damages for negligence or to pay compensation without regard to fault, I believe that, for the reasons just given, he should be required to carry insurance against his liability. Such insurance is now required not only in Massachusetts, but in Great Britain, Denmark, Finland and Norway. Motor vehicle common carriers are required to be insured by the Interstate Commerce Commission and by the laws of most of the states. ${ }^{5}$

\footnotetext{
${ }^{-}$For a discussion of these requirements, see Brownfield, Compulsory Liability Insturance for Commercial Motor Vehicles, supra, p. 57 I.
} 


\section{Compensation Without Regard to Fault}

\section{r. General Principles}

Until recently, it has been assumed by all concerned that liability in automobile accident cases should be based on fault. The importance of the problem now impels us to examine that assumption. Tort liability based on fault has in the past achieved a kind of rough and ready justice, and the principle was naturally extended to automobile accidents when they first occurred. Someone has been hurt; someone must lose in consequence; plainly the loser should be the one who has, if only for a second, forgotten or violated his duty toward his neighbor. Like every other social device, this system of liability should be subjected to the pragmatic test, and if we are reasonably sure that something else will work better, we should try it.

It seems to me that the compensation theory springs from a more realistic view of the problem than does the liability theory. The problem is how to distribute the losses caused by automobile accidents in a way best suited to the public welfare. Conceivably, the losses may be allowed to rest where they first fall, that is on the victim of the accident and often on his family, his landlord, his physician and his grocer; or they may be partly shifted to the shoulders of the motorist or of his insurance carrier under a scheme of liability for negligence; or they may be shifted, under a compensation scheme, to the motorists as a class or to all the taxpayers.

So far as I know, no one advocates the first of these courses, and I believe that the second has seemed satisfactory to us only because we have been unimaginative about it. We have not even known that there is a problem, because we have taken it for granted that the man who is at fault must pay and that there is nothing more to it. We have in many cases assumed that the "care exercised by a reasonable man" really means an unrelaxing care of which no man is capable; we have assumed that negligence and contributory negligence are always facts ascertainable by subsequent investigation and testimony; we have assumed that all motorists are able to pay if they are liable, and that the bargaining between the victim and a motorist or his insurance carrier results in the payment of a sum really representing the loss sustained or at least realizing a rather nebulous conception of justice. The truth is that many accidents are caused by a momentary forgetfulness on the part of the motorist or of a pedestrian which happens to coincide with other conditions to produce a collision; that we apportion the entire burden of loss according to the supposed culpabilities of that moment; that in many cases all the loss falls on the victim, while in most cases of serious injury the heaviest burden of loss falls on him even where there is payment by virtue of a liability insurance policy; that the process of settlement with an insurance carrier, which disposes of the great bulk of all cases of payment, results in payments not closely related to the severity of the injuries involved; and that a jury trial is a remarkably clumsy and expensive method of settling liability.

The above statement that in most cases of serious injury the heaviest burden of 
loss falls on the victim is supported by the committee's investigation. The report indicates that in insured non-fatal cases the surplus of amount received over amount of loss starts at a high figure for minor cases and becomes a deficit for serious cases. In insured fatal cases, there is usually a substantial payment in addition to the medical and funeral expense, though the amount received probably tends to be less than would have been received under a workmen's compensation law. ${ }^{8}$ In general, the permanently disabled receive least in proportion to their losses.

We should also remember that reasonable promptness in the payment of compensation is very important. In the cases investigated by the committee the minor claims were in general paid reasonably quickly, but of the permanent disability and fatal cases, half were not settled within six months after the accident and a third were not settled within a year. Under a compensation plan payments should be begun much more quickly, especially in cases of permanent disability in which a total temporary disability usually precedes the discovery of the permanent condition.

It seems to me that on principle a compensation plan, backed by compulsory insurance, would be a sensible way of meeting the problem, because it would recognize automobile accidents as inescapable perils of modern life and would seek to spread the loss of such accidents promptly, with an approach to certainty and without too much effort and expense. Many people are, I believe, already persuaded of the need for compulsory automobile liability insurance. The further step of abandoning the test of negligence is much longer in theory than in practise. In Massachusetts, under the compulsory liability insurance law, there is apparently already a strong leaning toward a system of liability without fault, although the degree of negligence or of contributory negligence no doubt partly controls the amount paid in each case. Of 1,749 cases studied by the committee in Boston and Worcester, in each of which the motorist was insured, there were only 139 , or $8 \%$, in which no payment was made by the insurance companies. ${ }^{7}$

If a compensation plan can be administered so as to spread losses as I have suggested, I believe that we should adopt it. Let me therefore examine some of the practical aspects of a compensation plan so as to help the reader to decide whether he thinks such a plan wórkable. For convenience, I shall comment on the plan outlined by the committee and published by the editor in this symposium. ${ }^{8}$

\section{Rates and Risks}

Premium Cost: When a man has said, "The compensation plan sounds good; let's see if it will work," he will probably think next of the probable cost to motorists. In this connection we should remember that the cost of a new kind of insurance can never be predicted accurately; if the insurance is desirable we can only make the best possible estimate and correct it later by experience. Assuming a scale of benefits

\footnotetext{
'See CommitteE's RePort, chap. V and tables. The workmen's compensation figures on fatal cases referred to in the text (see report p. 89) are based on very few cases and should be received with caution.

${ }^{2}$ See CoMmitTeE's Report, p. II 6 and note 19 , p. 130.

${ }^{8}$ Stipra, p. 580 .
} 
modeled on the New York workmen's compensation law, as in the plan outlined, the committee estimated that insurance in Massachusetts would cost not over $16 \mathrm{x} \%$ of the present cost of compulsory liability insurance. If the scale of benefits, instead of being modeled on the generous New York workmen's compensation law, were modeled on the less generous Massachusetts law, the percentage would be not over 98. We may fairly assume that any state adopting a compensation plan would adopt a scale of benefits about equivalent to the scale employed in its workmen's compensation law. Consequently, the probable amount of premiums in any state can be approximated by applying to $16 \mathrm{I} \%$ the experience differential for that state already calculated by the National Council on Compensation Insurance on a basis of Ioo for New York. Since New York has the most generous workmen's compensation law, it seems probable that the shift from liability insurance to compensation insurance would increase premiums by no more than $6 \mathrm{r} \%{ }^{\circ}$

These percentage calculations were made five years ago and $I$ have no doubt that they would be somewhat changed by up-to-date figures. They would of course be changed by experience under a compensation plan. Mr. Sherman's careful analysis of the committee's report refers to the estimate of cost as "a promise" by the committee. It will, I believe, be plain to a student of the report that it is simply an honest estimate.

Mr. Sherman argues that compulsory insurance costs more than voluntary insurance, because premiums have increased in certain Massachusetts zones. But the fact is that the average amount paid for losses per car has increased in Massachusetts about the same as elsewhere, so that the increase in premiums in such zones as Boston has been caused, not by increased losses due to the compulsory insurance law, but by a rearrangement of zones suggested by the more complete experience acquired under the law. I see no reason to conclude that the committee should have raised the estimate of premium cost for states other than Massachusetts on the ground that compulsory insurance costs more than voluntary insurance.

Mr. Sherman's other criticisms of the committee's cost calculation should be carefully considered before rates are set under a working plan. It seems probable that if compensation is adopted it will be preceded by a more wide-spread adoption of compulsory liability insurance, under which the state and the insurance carriers, working together, could gather more data than the committee could gather and would therefore be able to make a closer estimate of the cost of compensation insurance.

Fixing Rates: In Massachusetts the commissioner of insurance fixes the premiums for automobile liability insurance, while in Great Britain the companies continue to fix their own rates. For my part, I would be content to follow the British plan so

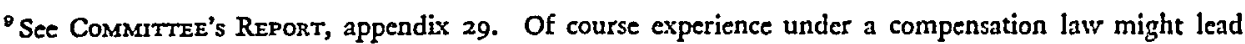
to re-zoning. Even in Massachusetts, where there has been nearly ten years of experience under compulsory liability insurance, it might be found under a compensation plan that differences in the proportions of earners injured or in the amounts of earnings or in the seriousness of injuries required a re-zoning of the state.
} 
long as competition fairly protected the motorists. But I doubt whether any state legislature would consent to do without regulation. If there is to be regulation I suggest that the carriers should maintain a rating bureau subject to state inspection and that the burden of disproving the rates should rest on the state. The unfortunate result of the Massachusetts system has been to make the rates a political issue and hence to fix rates which are unfair to the insurance companies.

Forcing Risks: In Massachusetts a motorist can apply to any company for a policy and if he is refused can ask the Board of Appeal to require the company to accept him. I would favor relying on the carriers to select their own risks, and I would require a motorist whom no carrier will insure to deposit cash or securities with the state authorities in lieu of taking out a policy. The carrier's only reason for refusing to write a policy is that the risk is too great, so that if the applicant can find no carrier to insure him, it is best for the public that the alternative requirement of a deposit shall make it difficult for him to go on the road. If the carriers abused their power the Massachusetts system would have to be resorted to.

\section{Coverage}

Basis of Liability: A compensation plan can impose liability either on the owners of vehicles or on individual operators. The former seems better because the insurance requirement can more certainly be enforced if policies cover cars rather than persons.

The liability can be for injury "caused by the operation of the motor vehicle," or for injury "caused by the operation of the motor vehicle and by its impact with any person or object." For most accidents these two bases of liability would be the same, for in most accidents a car hits a pedestrian or another car or a stationary object and it is quite clear that the accident is caused by the car or cars creating the impact. But there are some cases in which a cause of the accident is a car not in the collision. For instance, if one car strikes a pedestrian while swerving from the blinding headlights or from the improper course of another car, the car which causes the swerving is certainly one of the cars causing the accident. A basis of cause alone would encourage every insurance carrier to look for some such primary cause in every accident, and it therefore seems to me that the necessity of impact should be added. If the basis were cause alone, there would be a strong tendency in the cases first litigated to identify cause with the theory of proximate cause familiar in the law of torts, and hence to confuse cause with negligence.

Persons Compensated: Any plan would necessarily provide compensation to pedestrians. In fact, I believe that it would be reasonable to begin with pedestrians only and to extend coverage to others after a few years of experience as to cost and method of operation. Next come bicyclists, horsemen and occupants of horsedrawn vehicles, all of whom appear to be really in the same class as pedestrians. Occupants of motor vehicles present the most difficult problem. 
I believe that the driver of a car involved in an accident should not receive compensation unless he has collided with another motor vehicle. If an operator can receive compensation for injuries received from driving his car into a lamp-post, the temptation to fraudulent claims will be very great. Of course two dishonest operators could stage a collision so that each would claim compensation, but such a fraud would be harder to commit and less likely to be undertaken.

In states which now deny the liability of an operator for injuries to his guests, I suppose that a compensation law might deny compensation to passengers injured by collision with a stationary object. I understand that the guest statutes have been passed to prevent fraud, and of course the same kind of fraud, though requiring deliberate planning rather than subsequent mendacity, could be used to obtain money for guests under a compensation law. For my own part, I should not deny compensation to guests in such cases unless and until experience showed that fraud had become common. For example, it would be hard to exclude from benefits the passengers of a car which upset on a busy street in an effort to avoid a runaway trolley. A statute could not well be drawn distinguishing between such accidents occurring in the public eye and those occurring on back country roads where the dark designs of malefactors can be achieved in secret.

It seems necessary to exclude the owner of a motor vehicle from compensation unless he is hurt in a collision with another motor vehicle, for to require the owner to carry accident insurance for his own protection would probably be unconstitutional. For injuries caused by collision with another car the owner would collect compensation from the carrier insuring the other car. The wise owner would in addition carry accident insurance to protect himself in cases not covered by his statutory policy. Indeed, this suggests the possibilities of law in a totalitarian state; the dictator could there require every inhabitant to take out an accident policy and most of the problems with which this article is concerned would vanish in a moment.

Incidence of Liability: For injuries caused by the collision of two cars, the law can provide for the occupants of each car compensation from the carrier insuring that car or from the earrier insuring the other car, or a joint liability of both carriers for all injuries. In any event, the constitutional difficulty as to the owners should be remembered, as explained above. For collisions of three or more cars, somewhat similar principles would apply. The reader is referred to the committee's report for a more detailed discussion. ${ }^{10}$

Hit and Run and Out-of-State Cars: There will of course be victims of accidents for whom even a compensation plan can do nothing. The victim of the hit and run driver will be as helpless as now. The victim of the out-of-state car will have to depend, as he now does, on an action of tort, unless the other state also requires

${ }^{10}$ CoMMTrTEE's REPORT, p. 139, 237 et seq. 
compensation insurance. ${ }^{11}$ In other words a compensation plan will not plug up all the holes. But this is not a reason for refusing to plug up most of the holes, if the compensation principle makes a good plug as far as it goes.

Consent of Owner: Nor will the principle of compensation without regard to fault benefit the victim of one driving without the consent of the owner of the car. If the driver is a thief or a totally unauthorized borrower, the victim will stand where he is to-day, that is, he will have his action of tort against the culprit and he will probably recover nothing. How the victim will fare if the car was driven by a son of the owner who borrows it without his father's permission, or by a servant of the owner who extends a business trip to a joy ride, will depend on whether the compensation law makes any change in the pre-existing law as to liability because of agency or consent. Such a change is a matter really apart from the compensation principle, though the adoption of that principle will focus attention on the questions of agency and of consent. Certainly there is a strong argument in favor of imposing liability, whether with or without fault, for the acts of a son or of a servant who habitually uses the owner's car, for the victim of an accident in such cases is almost helpless in the face of any evidence which the defendant or his carrier may offer as to agency or consent.

Property Damage: It will be possible to include damage to property in a compensation plan or to leave the owner of the damaged property to his action of tort or, conceivably, to eliminate all claims for such damage. The figures as to property damage gathered for the committee's report are now a little stale, but they indicate a situation which I assume still exists. The number of property damage claims against insurance companies is more than twice the number of claims for bodily injury, though the money value of the property claims is only about one third the money value of the claims for bodily injury. In short, the number of cases of property damage is very great, but the amount involved in each case is relatively small.

The objections to including property damage in a compensation plan are that to do so would considerably increase premiums and would greatly increase the total number of claims to be adjudicated. There are many accidents in which there is property damage but no bodily injury, and though the money amount of the damage could be more readily agreed on, there would still be many disputed cases, involving relatively small sums, to be decided by the compensation officers. On the whole, it seems to me better to leave the owner of injured property to his tort claim. The matter of serious social consequence is the physical injury of accident victims, not the replacement of clothes, watches or even automobiles destroyed by accidents. This solution would probably make the collection of small property damage claims more difficult than at present. Motorists with no property would continue to be

11 The figures cited in note $16, \mathrm{p}$. 129 , of the Committee's Report indicate that non-resident cars were concerned in the following percentages of 1930 accidents: California 1.2; Connecticut 10.9; Massachusetts 6.5; New York 1.7; Rhode Island 11.7. 
irresponsible, and there might be a tendency among those with property to draw the line at an extra premium for property damage liability. Consequently the man who suffered a small property loss of say \$100 or less, finding an individual much less generous than an insurance company, would incline to pocket his loss rather than to sue.

Subrogation: There are cases in which the carrier writing a compensation policy could properly be subrogated to the common law rights of the accident victim against a third person. For example, if an automobile accident were caused partly by a trolley car, the carrier which paid compensation to the occupants of the automobile could be given the right to recover from the trolley company, in an action of tort for negligence, the amount of compensation so paid.

If any right of subrogation were given, the law should make it clear that the trial of the action to enforce this right was not to bring up the very questions of negligence which the compensation plan was intended to abrogate. Hence there should be no right to proceed by way of subrogation against other persons involved in the accident whose negligence may be found to have caused the accident.

Schedule of Benefits: It is probable that any state adopting a compensation plan would provide for wage earners a schedule of benefits similar to that of its workmen's compensation law. By analogy, those in gainful occupations, but not employed by others, would receive similar benefits. Since there would certainly be a maximum weekly benefit, the man who earns a substantial income, say $\$ 5,000$ or more a year, would receive under a compensation plan less than the amount of his verdict should be under the present law if he could prove negligence and a loss of earnings. However, the number of such victims is comparatively small ${ }^{12}$ and the number who can collect enough money to compensate for actual losses in serious cases is very much smaller. The man with a substantial income can, for a very small premium, carry accident insurance for his own protection. All things considered, I find that my heart cannot bleed profusely for the well-to-do citizens who would lose a few possibly enforcible claims for large damages and would procure instead truly enforcible claims for small sums.

The weekly amount to be paid to non-earners is a serious problem. The committee has suggested arbitrary sums, since it would certainly be difficult to find, for instance, the money loss caused by a housewife's illness. Of course the fixing of arbitrary sums would save a great deal of dispute, and for that reason the principle might even be extended to earners. In the long run it might well be better to fix a uniform weekly benefit for all earners. The argument against this is that it would encourage malingering by those earning small wages.

Permanent partial disability cases would of course cause trouble just as they do under workmen's compensation laws. In the committee's estimate of premium costs, the compensation for such cases makes up about half of the total compensa-

\footnotetext{
10 Of the earners investigated by the committee who were injured but not killed, $73 \%$ carned $\$ 37.50$ a week or less. See CoMmitten's RePoRT, p. 71, note I.
} 
tion, though the number of cases of permanent partial disability is less than a fourth of the total number of compensable cases. Under any system, the amounts awarded for permanent partial disabilities tend to become really lump sum awards paid in instalments and stated as so many weeks of a given percentage of the payee's earnings. Under an automobile compensation plan, non-earners would be especially tempted to exaggerate the extent of their permanent partial disabilities, because there would be no evidence of subsequent earning power to check their claims.

\section{Administration}

Adjudication of Claims: Under a compensation plan claims would be adjudicated by an administrative board with the help of referees. Possibly the existing workmen's compensation machinery would be increased to take in the new kind of cases. A system of agreed settlements should be able to dispose satisfactorily of a very large number of cases, for it would not be necessary to protect the claimant from the carrier as solicitously as the workman, who fears the loss of his job, is now protected in many states from the danger of unfair settlements.

As under workmen's compensation, the duration and the extent of disability would be the facts most often to be found by the referees. And as under workmen's compensation, the finding of fact would often be an informed guess, based on conflicting medical testimony and with a tendency to favor the claimant. In this respect referees are like juries, except that a referee soon learns a good deal about his job, while a juryman is often selected for his ignorance.

Choice of Physicians: One of the most serious difficulties of a compensation plan would be caused by the necessity for allowing injured persons to choose their own physicians. It is perhaps reasonable to require the injured workman to submit to the care of the physician furnished by his employer or by his employer's carrier, though this has led to one-sided medical testimony before referees and to the evils of insurance clinics. But when a man is injured in the street by a total stranger, certainly the law could not reasonably require him to submit to the care of the stranger's physician. In the case of an earner, the right of a motor victim to choose his own physician would be no more and no less objectionable than the similar right now enjoyed in some states by injured workmen; if the carrier's physician were promptly notified and were allowed to make periodic examinations, there would be real protection to the carrier. But where the injured person was not an earner, the desire to hold his job and to receive full wages would not impel him to get out of bed, and the danger of malingering and of exaggeration would be greater. This is a serious matter which must be frankly faced in the framing of an automobile compensation law by giving the carrier's physician sufficient chances to check, and perhaps by reducing the compensation payable to non-earners after a certain number of weeks.

Fraud: Except for the problem raised by the choice of physicians, and that is serious, I see no reason to suppose that compulsory compensation insurance would 
be more conducive to fraud than compulsory liability insurance. Under either system the motor victim would know that he has a carrier to look to. Whenever there is liability insurance the carrier now pays in the great majority of cases, apparently with little reference to negligence except as it controls the amount paid. In short, as soon as the victim finds that the motorist is insured, he concludes that Santa Claus will come to his house in due course, and that happy Christmas state of mind does not depend on the kind of insurance or on the universality of insurance among the motorists of the state.

Litigation: A sound argument for a compensation plan is the congestion of court calendars by accident litigation in the large cities. Compulsory liability insurance increases this congestion and of course increases with it the delays of trial litigation of all classes. To remove automobile accident trials from the courts will reduce their trial business in the big cities by from one-fifth to one-half. Of course an alternative is to increase the numbers of judges and of court rooms. This will appeal to those who are completely satisfied with the present system, but not to those who hesitate to fasten on us new office holders whom it will be difficult to dislodge if the system is changed.

The proportion of automobile accident claims tried is small. For example, in I930 the Travelers Insurance Company paid only $2 \%$ of 24,744 public liability claims in pursuance of verdicts. ${ }^{13}$ The number of claims tried for property damage alone is very small indeed, and it must be realized that under a compensation plan covering only bodily injuries, suits for property damage alone would almost cease to exist, for in most cases it would not pay to bring suit for the small sum involved, and it would no longer be possible to carry a property damage claim to victory on the coat tails of a claim for nervous shock or for night sweats.

The value of a compensation plan in relieving court congestion lies in the relief from delay extended to all classes of civil cases as well as in the relief extended to the automobile accident cases which reach trial.

Under a compensation plan there would at first be a good deal of litigation to settle the meaning of the statute. If cause alone were the basis of liability, I should expect litigation on that score to continue for a long time and to be considerable. In any event, there would always be appeals from the compensation board to the courts on questions of law, as there are now under the workmen's compensation laws. Aside from the basis of liability, I should expect these appeals to be concerned chiefly with the medical testimony in permanent partial disability cases and with the allocation of liability in cases involving more than one carrier. I should expect the litigation, when the law was well under way, to be no greater in proportion to the number of claims than in workmen's compensation. ${ }^{14}$ All of this litigation would be without juries. The volume of it in comparison with the volume of present automobile accident litigation is a matter of conjecture; my conjecture is that it would be very much less.

" COMMITIEE'S REPORT, P. 24, note 9.

${ }^{24}$ See CommitteE's Report, p. $16 \mathrm{Y}$, note 8. 


\section{Summary}

Every motorist should be required to insure against his liability for personal injuries and death, because experience shows that this is the only way to protect the public. If the state is to control the premiums, the political mistakes of Massachusetts must be avoided. For automobile accidents, a system of compensation without regard to fault, administered like workmen's compensation, would be better than the present system of liability for negligence only; because it is no longer realistic to apply the negligence test to automobile accident compensation; because such a system would more fairly distribute losses, particularly in serious cases; because payments would be prompter; and because the courts in the large cities would be relieved of a mass of litigation which is no longer suited for jury trial. The most serious problems are to estimate the cost of premiums, to prevent the fixing of premium rates from becoming a political issue, and to minimize fraudulent claims, especially by non-earners. 